\title{
Trace elements in size-segregated urban aerosol in relation to the anthropogenic emission sources and the resuspension
}

\author{
Dragana Đorđević • Angela Maria Stortini • \\ Dubravka Relić • Aleksandra Mihajlidi-Zelić • \\ Jasna Huremović • Carlo Barbante • Andrea Gambaro
}

Received: 20 February 2014 / Accepted: 1 May 2014 / Published online: 27 May 2014

(C) Springer-Verlag Berlin Heidelberg 2014

\begin{abstract}
Size segregated particulate samples of atmospheric aerosols in urban site of continental part of Balkans were collected during 6 months in 2008. Six stages impactor in the size ranges: $\mathrm{Dp} \leq 0.49 \mu \mathrm{m}, 0.49<\mathrm{Dp} \leq 0.95 \mu \mathrm{m}, 0.95<$ $\mathrm{Dp} \leq 1.5 \mu \mathrm{m}, 1.5<\mathrm{Dp} \leq 3.0 \mu \mathrm{m}, 3.0<\mathrm{Dp} \leq 7.2 \mu \mathrm{m}$, and $7.2<$ $\mathrm{Dp} \leq 10.0 \mu \mathrm{m}$ was applied for sampling. ICP-MS was used to quantify elements: Al, $\mathrm{As}, \mathrm{Bi}, \mathrm{Ca}, \mathrm{Cd}, \mathrm{Co}, \mathrm{Cr}, \mathrm{Cu}, \mathrm{Fe}, \mathrm{Ga}, \mathrm{K}$, $\mathrm{Li}, \mathrm{Na}, \mathrm{Ni}, \mathrm{Mg}, \mathrm{Mn}, \mathrm{Pb}, \mathrm{Sb}, \mathrm{V}$, and $\mathrm{Zn}$. Two main groups of elements were investigated: (1) K, V, Ni, Zn, Pb, As, and $\mathrm{Cd}$ with high domination in nuclei mode indicating the combustion processes as a dominant sources and (2) $\mathrm{Al}, \mathrm{Fe}, \mathrm{Ca}, \mathrm{Mg}$,
\end{abstract}

Responsible editor: Gerhard Lammel

D. Đorđević $(\bowtie) \cdot$ A. Mihajlidi-Zelić

University of Belgrade, Centre of Chemistry-ICTM, Studentski trg

14-16, 11000 Belgrade, Serbia

e-mail: dragadj@chem.bg.ac.rs

\section{A. M. Stortini}

Department of Molecular Sciences and Nanosystems, University Ca' Foscari of Venice, Dorsoduro 2137, 30123 Venice, Italy

\section{Relić}

Faculty of Chemistry, University of Belgrade, Studentski trg 12-16, 11000 Belgrade, Serbia

\section{J. Huremović}

Department of Chemistry, Faculty of Science, University of Sarajevo, Zmaja od Bosne 33-35, 71000 Sarajevo, Bosnia and Herzegovina

\section{Barbante $\cdot$ A. Gambaro}

Department of Environmental Sciences, Informatics and Statistics, University Ca' Foscari of Venice, Dorsoduro 2137, 30123 Venice, Italy

\section{Barbante $\cdot$ A. Gambaro}

Institute for the Dynamics of Environmental Processes-National Research Council (CNR-IDPA), Dorsoduro 2137, 30123 Venice, Italy
$\mathrm{Na}, \mathrm{Cr}, \mathrm{Ga}, \mathrm{Co}$, and $\mathrm{Li}$ in coarse mode indicating mechanical processes as their main origin. The strictly crustal origin is for $\mathrm{Mg}, \mathrm{Fe}, \mathrm{Ca}$, and $\mathrm{Co}$ while for $\mathrm{As}, \mathrm{Cd}, \mathrm{K}, \mathrm{V}, \mathrm{Ni}, \mathrm{Cu}, \mathrm{Pb}$, and $\mathrm{Zn}$ dominates the anthropogenic influence. The PCA analysis has shown that main contribution is of resuspension $\left(\mathrm{PC} 1, \sigma^{2} \approx\right.$ $30 \%$ ) followed by traffic (PC2, $\sigma^{2} \approx 20 \%$ ) that are together contributing around $50 \%$ of elements in the investigated urban aerosol. The EF model shows that major origin of $\mathrm{Cd}$, $\mathrm{K}, \mathrm{V}, \mathrm{Ni}, \mathrm{Cu}, \mathrm{Pb}, \mathrm{Zn}$, and $\mathrm{As}$ in the fine mode is from the anthropogenic sources while increase of their contents in the coarse particles indicates their deposition from the atmosphere and soil contamination. This approach is useful for the assessment of the local resuspension influence on element's contents in the aerosol and also for the evaluation of the historical pollution of soil caused by deposition of metals from the atmosphere.

Keywords Urban aerosol · Size segregated of trace elements · The processes responsible for their origin

\section{Introduction}

The knowledge of the size distributions of trace elements in atmospheric particles is important not only because of inhalation affects but also for control which metals may be dispersed through the atmospheric transport and the evaluation of depositions rates to the Earth's surface.

The size distribution of trace elements and metals bonded to atmospheric particles is crucial in understanding the health effects by inhalation, in evaluation their sources and assessing their lifetime in the atmosphere. Primary particles of natural origin generated by mechanical processes including soil erosion, sea spray, or industrial mechanical processes are composed of crustal elements (Seinfeld and Pandis 1998). Urban areas are rich in anthropogenic 
sources of fine particles containing harmful metals and trace elements. Traffic, energy production, and industrial combustion are main urban emission sources of elements from fossil fuels. So, Ni and V are tracers of fossil fuels burning (Suarez and Ondov 2002; Moffet et al. 2008) and the use of tetra-ethyl-lead as a gasoline additive resulted in emission of submicron lead particles (Murphy et al. 2007; Moffet et al. 2008). Trace elements of anthropogenic origin released into atmosphere in high temperature processes: combustion of fossil fuels, wood, and waste (Allen et al. 2001) or metal working (Ondov and Wexler 1998). Elements originating from the same source have the similar size-distribution (Ondov and Wexler 1998).

Trace metals are found in almost all atmospheric aerosol size fractions. Accumulation mode $(0.1-1.0 \mu \mathrm{m})$ deposit slowly and can therefore be transported over long distances from their sources, having consequent effects in remote regions (Allen et al. 2001). Also, the size distributions can provide information about proximity of the sources to the sampling site. So, levels of primary ultrafine particles (less of $0.1 \mu \mathrm{m}$ ) are the highest close to their sources (Reponen et al. 2003).

The resuspended surface dust make a large contribution to the total natural emission, accounting for $>50 \%$ of $\mathrm{Cr}$, $\mathrm{Mn}$, and $\mathrm{V}$, and $>20 \%$ of $\mathrm{Cu}, \mathrm{Mo}, \mathrm{Ni}, \mathrm{Pb}, \mathrm{Sb}$ and $\mathrm{Zn}$ and, volcanic activities contributing by $20 \%$ of atmospheric $\mathrm{Cd}$, $\mathrm{Hg}, \mathrm{As}, \mathrm{Cr}, \mathrm{Cu}, \mathrm{Ni}, \mathrm{Pb}$, and Sb (Pacyna 1998; Allen et al. 2001). The dominant contribution of the local resuspension to particulate matter levels has been reported by Đorđević et al. 2004. The study of the local topsoil contribution to airborne particulate matter in the area of Rome has shown compositional differences among main geological domains and rock types of this area. A significant enrichment in $\mathrm{Pb}$, $\mathrm{Ni}$, and $\mathrm{Cr}$ has been observed in the $\mathrm{PM}_{10}$ resuspended fraction of either volcanic or sedimentary outcropping rocs (Pietrodangelo et al. 2013).

The crustal enrichment factors indicate that the freeway traffic contribute to enrich levels of ultrafine $\mathrm{Cu}, \mathrm{Ba}, \mathrm{P}$ and $\mathrm{Fe}$, and possibly $\mathrm{Ca}$. In addition, this study shows that trace elements constitute a small fraction of PM mass in nanoparticle size rang with high importance to human health (Ntziachristos et al. 2007). Handler et al. (2008) have reported that trace metal emissions (As, $\mathrm{Ba}, \mathrm{Cd}, \mathrm{Co}, \mathrm{Cr}, \mathrm{Cu}, \mathrm{Mn}, \mathrm{Ni}$, $\mathrm{Pb}, \mathrm{Sb}, \mathrm{Sr}, \mathrm{Ti}, \mathrm{V}, \mathrm{Zn}$ ) contributed less than $1 \%$ of total emissions in all size fractions. The resuspension is dominant process for emissions of coarse particles whereas combustion processes are dominant for emission of elements in fine particles (Handler et al. 2008). The atmospheric concentrations of $\mathrm{P}, \mathrm{K}, \mathrm{Mn}, \mathrm{Cu}, \mathrm{Mo}, \mathrm{Pb}, \mathrm{Mg}, \mathrm{S}, \mathrm{Ca}$, and especially $\mathrm{Fe}$, are associated with both traffic and non-traffic sources, and various studies are in very good agreement with this except for the relative abundance of $\mathrm{Mg}, \mathrm{Ca}$, and $\mathrm{Fe}$ in road dust depending on locations (Ning et al. 2008).
The study that was performed in Dresden at the busy main street has shown that local sources such as traffic and heating are influencing on $\mathrm{Cu}, \mathrm{Cr}, \mathrm{Fe}, \mathrm{Mn}, \mathrm{Zn}, \mathrm{Ga}, \mathrm{Si}$, and Ti contents in atmospheric aerosol and that the influence of the air masses origin is insignificant. The same study showed crustal enrichment factors (CEFs) $>100$ for $\mathrm{Pb}, \mathrm{Zn}$ and $\mathrm{Cu}$ for all particle sizes indicating strong anthropogenic influence. The dominant source for $\mathrm{Zn}$ was coal burning as well as for $\mathrm{Pb}$ in the winter period while biomass burning is the main source for K. Also, concentrations of $\mathrm{Pb}$ and $\mathrm{K}$ in urban atmospheric aerosol of Dresden are the highest in air masses from the East (Brüggemann et al. 2009).

The results of concentrations of metals in Oxford aerosols have shown that $\mathrm{Fe}, \mathrm{Mn}, \mathrm{Sr}$, and $\mathrm{Cu}$ mainly found in particles $>1 \mu \mathrm{m}$, the size fraction associated with resuspension of soil and road dust, while $\mathrm{V}, \mathrm{Ni}, \mathrm{Cd}$ and $\mathrm{Pb}$ were predominantly present in smaller particles, $<1 \mu \mathrm{m}$, suggesting high-temperature sources for these metals (Witt et al. 2010).

Number of studies regarding ambient particulate matter source apportionment using receptor models has been done (Belis et al. 2013). The study of the chemical composition and sources of fine and coarse aerosol particles in the Eastern Mediterranean (Finokalia-Create) have shown the significant correlation between $\mathrm{Ti}, \mathrm{Fe}, \mathrm{Mn}$, and $\mathrm{Ca}$, and these elements have high loadings in the first component for the coarse mode, together with $\mathrm{Ni}$ and $\mathrm{V}$, with moderate loading within the first component, explains $43.1 \%$ of the total variance. In the fine mode, $\mathrm{Ca}, \mathrm{Fe}$, $\mathrm{Mn}$, and $\mathrm{Ca}$ have high loadings in the first component with $28.1 \%$ of the total variance attributed to crustal component and second factor accounting $12.5 \%$ of the total variance with high loadings for $\mathrm{V}$ and Ni may be attributed to heavy oil combustion (Koulouri et al. 2008). Vanadium in fine particles was selected as an indicator for emission from ship traffic source (Zhao et al. 2013). An investigation of traffic emission on Hatfield Tunnel shows that metals form average $27 \%$ of total $\mathrm{PM}_{10}$ (Lawrence et al. 2013). The similar investigation in Marquês de Pombal tunnel (Pio et al. 2013) shows that $\mathrm{Al}, \mathrm{Fe}, \mathrm{Mn}, \mathrm{Cu}$, etc., concentrated in the coarser size ranges are mainly emitted from mechanical processes (road resuspension, wear of brakes, and tires) while $\mathrm{Zn}, \mathrm{V}$, $\mathrm{Pb}, \mathrm{Cd}, \mathrm{Ba}$, etc., appear to have a dual origin inside the engine and in mechanical wear.

Study in Patras has shown that local sources other than traffic, were found to contribute approximately $20 \%$ and the rest was attributed to long range transport. Biomass burning was identified as a winter source, but it could not be concluded whether it was local or transported. Domestic heating was identified as the dominant winter source and was found to increase PM levels sharply during nighttime. Two fuels are commonly used in the area, diesel and wood (Pikridas et al. 2013). 
The aim of the present study is to clarify the processes causing the presence of elements in atmospheric aerosols and explain their sources in urban area of continental part of Balkan Peninsula.

\section{Experimental methods}

Samples were collected in the urban area, downtown of Belgrade, from June to December 2008 (Lat. $44^{\circ} 49^{\prime} 10.08^{\prime \prime} \mathrm{N}-$ Long. $20^{\circ} 27^{\prime} 32.47^{\prime \prime} \mathrm{E}-113 \mathrm{~m}$ above sea level). Belgrade, the capitol of Serbia, is located at the confluence of the rivers Sava and Danube and has a population of about two million inhabitants. Total number of vehicles in Belgrade is about 500,000. Majority of them are passenger cars, whose average age is more than 15 years (Aničić et al. 2009). In the investigated period, leaded gasoline $\left(0.4 \mathrm{~g} \mathrm{l}^{-1} \mathrm{~Pb}\right)$ was still used. For the District Heating System of the city of Belgrade, the heating energy is produced in 60 heating sources-15 large heating plants and 45 boiler rooms with a total capacity of $2,868 \mathrm{MW}$, which mainly use natural gas or heavy fuel oil (Public Utility Company Beogradske elektrane). Fuel used for domestic heating in individual heating facilities consists mainly of coal or heavy fuel oil.

Belgrade is located in a continental climate region. The average annual air temperature is $12.5^{\circ} \mathrm{C}$. The warmest month is July with an average temperature of $23{ }^{\circ} \mathrm{C}$, and the coldest month is January with an average temperature of $1.4{ }^{\circ} \mathrm{C}$. The average annual rainfall is $690.91 \mathrm{~m}^{-2}$. The maximum monthly precipitation occurs in June and the minimum in February. The wind most frequently blows from west-northwest and south-southeast directions (Republic Hydrometeorological Service of Serbia). Wind of moderate to strong intensity coming from southeast direction, called Košava, occurs more often during autumn and winter.

Size-segregated aerosol in 32 samples sets (corresponding to 192 samples) were collected every sixth day by a High Volume Cascade Impactor, Model TE-236. Time interval per sample was 48 hours, and the average air volume sampled was $3,500 \mathrm{~m}^{3}$. Each sample set comprised six atmospheric aerosol samples: three that are representing the coarse mode in the ranges of $1.5<\mathrm{Dp} \leq 3.0 \mu \mathrm{m}\left(\mathrm{PM}_{1.5-3.0}\right), 3.0<\mathrm{Dp} \leq 7.2 \mu \mathrm{m}$ $\left(\mathrm{PM}_{3.0-7.2}\right)$, and $7.2<\mathrm{Dp} \leq 10.0 \mu \mathrm{m}\left(\mathrm{PM}_{7.2-10}\right)$ and three that are representing fine mode in the ranges of $\mathrm{Dp} \leq 0.49 \mu \mathrm{m}$ $\left(\mathrm{PM}_{<0.49}\right), 0.49<\mathrm{Dp} \leq 0.95 \mu \mathrm{m}\left(\mathrm{PM}_{0.49-0.95}\right)$, and $0.95<\mathrm{Dp} \leq$ $1.5 \mu \mathrm{m}\left(\mathrm{PM}_{0.95-1.5}\right)$ (Đorđević et al. 2012).

Gravimetric measurements and sample processing have been performed in a clean room environment and glove box system with nitrogen atmosphere and the filters were kept at a temperature $\left(20 \pm 5^{\circ} \mathrm{C}\right)$ and humidity $(45 \pm 5 \%)$ For gravimetric measurements, a KERN ABT 120-5DM balance (accuracy class I and precision of $0.01 \mathrm{mg}$ ) was used according the procedure reported by Stortini et al. (2009).
Before their use, filters in mixed cellulose ester were washed in $1 \% \mathrm{HNO}_{3}$ for $24 \mathrm{~h}$, dried in a clean room (class $100)$ environment and stored singularly. Blanks correspond to a set of filters deposed for few minutes (without being sampled) between two sample sets. Samples and blanks were stored in freeze $\left(-20{ }^{\circ} \mathrm{C}\right)$ till their analytical processing.

Sampled and blank filters were digested by Milestone ${ }^{\circledR}$ HPR-1000/10S High Pressure temperature-controlled microwave oven (Buccolieri et al. 2005). Eight of ten vessels were used for samples (half of filter per vessel) while two of them were used only for reagents (blank control for reagents). To avoid gas emission during the digestion procedure, vessels with filters and reagents where left $1 \mathrm{~h}$ at room temperature before digestion. The program for digestion includes $1 \mathrm{~h}$ at $60{ }^{\circ} \mathrm{C}$ followed by a sequence of steps that let samples reach $180{ }^{\circ} \mathrm{C}$ after $2 \mathrm{~h}$. The choice of the time for samples digestion is due to the composition of filter (mixed cellulose ester). In fact, for the cut off $<0.49 \mu \mathrm{m}, 3 \mathrm{ml}$ of distillate water was added to reagents and sample to avoid dry or explosion episodes during digestion. Samples recovering where performed as described by Stortini et al. (2009).

An Inductively Coupled Plasma-Quadrupole Mass Spectrometry (ICP-QMS-Agilent 7500I) with an octopole collision cell technology was used for trace element measurements. Such technology reduces interferences of ions.

Tuning procedure was performed with a $1 \mathrm{ppb}$ multielemental solution of 10 elements. Counts were checked for $\mathrm{Li}$ (7), Y (89), and $\mathrm{Tl}$ (205) and were assumed acceptable when values were higher than 7,000 counts. Ce (140) was considered in oxide ratio (156/140) and double charge ratio $(70 / 140)$ and values for both were kept $\leq 1 \%$. To correct loss of sensitivity, a $10 \mathrm{ppb}$ internal standard of In (115) was used.

\section{Results and discussion}

Elements concentrations in samples have been obtained after subtraction of the field blank values, and the limit of detection (LOD) was calculated for each element using the formula $\mathrm{LOD}=3 \sigma$ where $3 \sigma$ corresponds to three times the standard deviation (SD) of the blank value; values lower than the LOD were reported as non-detected. The accuracy and precision of the method was controlled using the standard reference material (Urban Particulate Matter NIST $\left.{ }^{\circledR} 1684 \mathrm{a}\right)$ and the relative error was calculated using the formula $R E \%=V_{\text {det }}-V_{\text {cert }} / V_{\text {cert }} \times 100$ in which $\mathrm{V}_{\text {det }}$ is the determined value and $\mathrm{V}_{\text {cert }}$ is the certified value (Table 1). 
Table 1 Accuracy evaluated against the standard reference material (Urban Particulate Matter NIST ${ }^{\circledR} 1684 a$ )

\begin{tabular}{llll}
\hline Element & $\begin{array}{l}\text { Determined value } \\
\left(\mathrm{mg} \mathrm{kg}^{-1}\right)\end{array}$ & $\begin{array}{l}\text { Certified value } \\
\left(\mathrm{mg} \mathrm{kg}^{-1}\right)\end{array}$ & $\mathrm{RE} \%$ \\
\hline $\mathrm{Na}$ & 4,240 & 3,565 & -16 \\
$\mathrm{Mg}$ & 8,130 & 7,514 & -8 \\
$\mathrm{Al}$ & 34,300 & 30,116 & -12 \\
$\mathrm{~K}$ & 10,560 & 10,755 & +2 \\
$\mathrm{~V}$ & 127 & 125 & -1 \\
$\mathrm{Cr}$ & 402 & 455 & +13 \\
$\mathrm{Mn}$ & 790 & 793 & +0.4 \\
$\mathrm{Fe}$ & 39,200 & 45,598 & +16 \\
$\mathrm{Co}$ & 17.93 & 15.99 & -11 \\
$\mathrm{Ni}$ & 81.1 & 77.8 & -4 \\
$\mathrm{Cu}$ & 610 & 507 & -17 \\
$\mathrm{Zn}$ & 4,800 & 5,377 & +12 \\
$\mathrm{As}$ & 115.5 & 120.24 & +4 \\
$\mathrm{Cd}$ & 73.7 & 71.8 & -3 \\
$\mathrm{Sb}$ & 45.4 & 45.6 & +0.4 \\
$\mathrm{~Pb}$ & 6,550 & 5,932 & -9 \\
$\mathrm{U}$ & 5.50 & 6.00 & 9 \\
\hline
\end{tabular}

The size-segregated and average values of mass concentrations of particulate matter (PM) with their standard deviations and size-segregated of trace elements mass concentrations are reported in Table 2. The highest values of size-segregated particulate concentrations have been obtained in the fine mode fractions $\left(\mathrm{PM}_{<0.49}\right)$. The domination of the fine mode has evidenced in whole investigated period (Fig. 1), and also, the concentration of PM has the highest value in $\mathrm{PM}_{<0.49}$ fraction (Table 2). A bimodal mass size distribution with peaks at the size ranges of $\mathrm{PM}_{<0.49}$ and $\mathrm{PM}_{3.0-7.2}$, was identified that is in accordance with distributions obtained by Song and Gao (2011), where the general size distributions of the mass concentrations did not changed significantly with seasons.

We quantified 23 elements: $\mathrm{Al}, \mathrm{As}, \mathrm{Bi}, \mathrm{Ca}, \mathrm{Cd}, \mathrm{Co}$, $\mathrm{Cr}, \mathrm{Cu}, \mathrm{Fe}, \mathrm{Ga}, \mathrm{K}, \mathrm{Li}, \mathrm{Na}, \mathrm{Ni}, \mathrm{Mg}, \mathrm{Mn}, \mathrm{Pb}, \mathrm{Sb}, \mathrm{V}$, and $\mathrm{Zn}$ in size-segregated concentrations ranged from pictograms to micrograms per cubic meter in dependence with the element. In addition, size-segregated total mass concentrations are given to evaluate overall presence of elements in the investigated sample set. Relative contributions of investigated elements vary through modes. The lowest contribution of the sum of elements is in $\mathrm{PM}_{<0.49}$ fraction $(3.8 \%)$ while the highest contribution $(11.1 \%)$ is found in $\mathrm{PM}_{1.5-3.0}$ fraction (Table 2). In general, the contribution of $\mathrm{Al}, \mathrm{Fe}, \mathrm{K}, \mathrm{Ca}, \mathrm{Mg}$ and $\mathrm{Na}$ is the dominant. Crustal elements: $\mathrm{Al}, \mathrm{Fe}, \mathrm{Ca}, \mathrm{Mg}$ are distributed in the fine and the coarse mode but, size segregated $\mathrm{K}$ shows domination in the fine mode. The second group of elements: $\mathrm{Zn}, \mathrm{Pb}, \mathrm{V}, \mathrm{Ni}, \mathrm{Mn}, \mathrm{Cu}$, and As have moderate contributions and except $\mathrm{Mn}$ and $\mathrm{Cu}$ their concentrations are dominating in the fine mode. The third group of elements: $\mathrm{Sb}, \mathrm{Cr}, \mathrm{Cd}, \mathrm{Mo}, \mathrm{Ga}, \mathrm{Co}$, $\mathrm{Li}, \mathrm{Tl}, \mathrm{Bi}$, and $\mathrm{U}$ are with the negligible contribution. Some of them are with bimodal distribution $(\mathrm{Cr}, \mathrm{Mo}$, $\mathrm{Ga}, \mathrm{Co}, \mathrm{Li}, \mathrm{Tl}$, and $\mathrm{Bi}$ ) and, bimodal with domination the fine mode for $\mathrm{Sb}$ while $\mathrm{Cd}$ is strongly dominating in the fine mode (Table 2, Fig. 2). The study performed in Dresden has shown that the most of the $\mathrm{K}, \mathrm{Pb}$, and $\mathrm{Zn}$ were found in fine particles $\left(\mathrm{PM}_{0.42-1.2}\right), \mathrm{Na}, \mathrm{Mg}, \mathrm{Ca}$, $\mathrm{Ti}, \mathrm{Si}$, and $\mathrm{Cu}, \mathrm{Fe}$ dominated in the coarse mode $\left(\mathrm{PM}_{1.2-3.5}\right)$ and $\mathrm{Cr}, \mathrm{Mn}$, and $\mathrm{Ni}$ showed a multimodal mass size distribution (Brüggemann et al. 2009). Two measurement campaigns carried out in Prague city near busy freeway and suburban crossroad (Ondráček et al. 2011) showed that main contribution of traffic in ultrafine size range can be attributed to direct exhaust emissions, while the coarse fraction was dominated mainly by regional background aerosol with small traces of brake and tyre abrasion as well as the resuspension of the road dust. Most of major elements were found in coarse fraction of mass size distribution and it were attributed to three different sources: abrasion of different vehicle parts $(\mathrm{Fe}, \mathrm{Cu}, \mathrm{Mn}$ and $\mathrm{Zn})$, resuspension of the road dust $(\mathrm{Si}, \mathrm{Al}, \mathrm{Ca})$, and long range transport or regional background $(\mathrm{Ca}$ and $\mathrm{K})$.

\section{Statistical analysis}

\section{Principal component analysis}

Principal component analysis (PCA) is a method with different variants of PCA that produce linear combination of the variables in the data set. These linear combinations represent factors (principal components) which are directly related to the contributions of emission sources (Seinfeld and Pandis 1998). The first principal component (PC1) represents the largest variation; $\mathrm{PC} 2$ is orthogonal to $\mathrm{PC} 1$ and represents the direction of the largest residual variation around PC1. PC3 is orthogonal to the first two and represents the direction of the highest, residual variation around the plane of PC1 and PC2, etc. (Tsitouridou et al. 2013).

PCA for each sub data set of $D p$ fraction was carried out using the data set with 23 variables, and in general, they explain over $85 \%$ of the total variance for each sub data set. In Table 3, results from principal component analysis are summarized. In each sub data set representing $D p$ fraction, the first principal component (PC1) is dominant and has the largest value of variance 
Table 2 Mass concentrations ( $\mathrm{ng} \mathrm{m}^{-3}$ ), mean \pm standard deviation $(\sigma)$, of elements distributed through $D p$ intervals obtained in the measured campaign

\begin{tabular}{|c|c|c|c|c|c|c|}
\hline & $\begin{array}{l}\mathrm{PM}_{<0.49} \\
\mathrm{C} \pm \sigma\end{array}$ & $\begin{array}{l}\mathrm{PM}_{0.49-0.95} \\
\mathrm{C} \pm \sigma\end{array}$ & $\begin{array}{l}\mathrm{PM}_{0.95-1.5} \\
\mathrm{C} \pm \sigma\end{array}$ & $\begin{array}{l}\mathrm{PM}_{1.5-3.0} \\
\mathrm{C} \pm \sigma\end{array}$ & $\begin{array}{l}\mathrm{PM}_{3.0-7.2} \\
\mathrm{C} \pm \sigma\end{array}$ & $\begin{array}{l}\mathrm{PM}_{>7.2} \\
\mathrm{C} \pm \sigma\end{array}$ \\
\hline PM & $7,900 \pm 5,000$ & $2,700 \pm 1,500$ & $1,800 \pm 1,000$ & $2,000 \pm 1,200$ & $3,300 \pm 2,000$ & $1,300 \pm 800$ \\
\hline $\mathrm{Al}$ & $42.74 \pm 58.50$ & $29.40 \pm 29.74$ & $34.35 \pm 31.28$ & $42.50 \pm 41.05$ & $65.37 \pm 45.64$ & $27.09 \pm 19.52$ \\
\hline $\mathrm{Fe}$ & $48.94 \pm 34.54$ & $34.83 \pm 21.45$ & $58.39 \pm 38.15$ & $75.60 \pm 50.33$ & $104.80 \pm 59.54$ & $38.64 \pm 19.41$ \\
\hline $\mathrm{K}_{\mathrm{tot}}$ & $95.62 \pm 57.12$ & $21.03 \pm 12.56$ & $9.74 \pm 7.86$ & $10.67 \pm 12.04$ & $18.23 \pm 15.53$ & $6.68 \pm 6.68$ \\
\hline $\mathrm{Ca}_{\text {tot }}$ & $38.36 \pm 38.57$ & $23.95 \pm 14.58$ & $41.38 \pm 24.91$ & $60.27 \pm 39.28$ & $102.36 \pm 58.92$ & $47.80 \pm 23.14$ \\
\hline $\mathrm{Mg}_{\text {tot }}$ & $11.38 \pm 13.02$ & $7.14 \pm 6.55$ & $8.92 \pm 6.89$ & $11.55 \pm 9.65$ & $18.60 \pm 12.53$ & $7.85 \pm 4.99$ \\
\hline $\mathrm{Na}_{\text {tot }}$ & $14.35 \pm 7.03$ & $11.06 \pm 8.11$ & $9.66 \pm 5.18$ & $11.17 \pm 8.32$ & $15.53 \pm 3.00$ & $5.21 \pm 3.43$ \\
\hline $\mathrm{Zn}$ & $28.17 \pm 26.25$ & $2.99 \pm 1.87$ & $2.96 \pm 2.10$ & $2.93 \pm 2.94$ & $4.61 \pm 5.27$ & $2.06 \pm 1.98$ \\
\hline $\mathrm{Pb}$ & $9.40 \pm 7.00$ & $3.34 \pm 4.44$ & $2.98 \pm 3.50$ & $2.60 \pm 4.13$ & $3.57 \pm 5.18$ & $1.35 \pm 1.96$ \\
\hline V & $2.59 \pm 2.37$ & $0.33 \pm 0.25$ & $0.28 \pm 0.18$ & $0.26 \pm 0.16$ & $0.37 \pm 0.23$ & $0.15 \pm 0.08$ \\
\hline $\mathrm{Ni}$ & $1.14 \pm 0.96$ & $0.21 \pm 0.13$ & $0.19 \pm 0.12$ & $0.19 \pm 0.11$ & $0.28 \pm 0.17$ & $0.09 \pm 0.05$ \\
\hline $\mathrm{Mn}$ & $1.55 \pm 0.82$ & $0.83 \pm 0.43$ & $0.91 \pm 0.48$ & $1.10 \pm 0.67$ & $1.61 \pm 0.87$ & $0.75 \pm 0.32$ \\
\hline $\mathrm{Cu}$ & $1.87 \pm 0.91$ & $0.95 \pm 0.40$ & $1.25 \pm 0.68$ & $1.51 \pm 0.88$ & $2.08 \pm 1.07$ & $0.71 \pm 0.32$ \\
\hline As & $1.23 \pm 1.13$ & $0.23 \pm 0.21$ & $0.17 \pm 0.16$ & $0.14 \pm 0.16$ & $0.17 \pm 0.19$ & $0.05 \pm 0.06$ \\
\hline $\mathrm{Sb}$ & $0.497 \pm 0.413$ & $0.130 \pm 0.091$ & $0.215 \pm 0.158$ & $0.245 \pm 0.191$ & $0.293 \pm 0.203$ & $0.100 \pm 0.059$ \\
\hline $\mathrm{Cr}$ & $0.243 \pm 0.121$ & $0.137 \pm 0.061$ & $0.151 \pm 0.095$ & $0.240 \pm 0.146$ & $0.340 \pm 0.194$ & $0.112 \pm 0.062$ \\
\hline $\mathrm{Cd}$ & $0.198 \pm 0.174$ & $0.041 \pm 0.040$ & $0.017 \pm 0.020$ & $0.007 \pm 0.008$ & $0.005 \pm 0.006$ & $0.003 \pm 0.006$ \\
\hline Mo & $0.124 \pm 0.150$ & $0.095 \pm 0.161$ & $0.117 \pm 0.172$ & $0.126 \pm 0.162$ & $0.145 \pm 0.166$ & $0.178 \pm 0.158$ \\
\hline $\mathrm{Ga}$ & $0.053 \pm 0.032$ & $0.036 \pm 0.023$ & $0.042 \pm 0.028$ & $0.054 \pm 0.038$ & $0.077 \pm 0.051$ & $0.030 \pm 0.020$ \\
\hline Co & $0.013 \pm 0.019$ & $0.005 \pm 0.009$ & $0.038 \pm 0.013$ & $0.044 \pm 0.018$ & $0.058 \pm 0.031$ & $0.034 \pm 0.011$ \\
\hline $\mathrm{Li}_{\text {tot }}$ & $0.025 \pm 0.039$ & $0.009 \pm 0.019$ & $0.022 \pm 0.027$ & $0.028 \pm 0.032$ & $0.043 \pm 0.038$ & $0.017 \pm 0.015$ \\
\hline $\mathrm{Tl}$ & $0.017 \pm 0.007$ & $0.008 \pm 0.003$ & $0.016 \pm 0.005$ & $0.015 \pm 0.005$ & $0.014 \pm 0.005$ & $0.014 \pm 0.005$ \\
\hline $\mathrm{Bi}$ & $0.028 \pm 0.021$ & $0.016 \pm 0.011$ & $0.018 \pm 0.013$ & $0.018 \pm 0.015$ & $0.020 \pm 0.014$ & $0.009 \pm 0.006$ \\
\hline $\mathrm{U}$ & $0.022 \pm 0.011$ & $0.023 \pm 0.011$ & $0.004 \pm 0.003$ & $0.004 \pm 0.003$ & $0.005 \pm 0.003$ & $0.003 \pm 0.002$ \\
\hline$\%$ of $\mathrm{PM}^{\mathrm{a}}$ & 3.8 & 5.0 & 9.6 & 11.1 & 10.2 & 10.6 \\
\hline
\end{tabular}

${ }^{\text {a }}$ Percentage of PM calculated from the averaged mass concentrations of the elements

$\left(\sigma^{2} \approx 30 \%\right.$ and higher). All fractions contain elements originating from resuspension $(\mathrm{Al}, \mathrm{Ca}, \mathrm{Co}, \mathrm{Cr}, \mathrm{Ga}, \mathrm{Fe}$, $\mathrm{Li}, \mathrm{Mg}, \mathrm{Mn}$ ) with their domination in the coarse mode.
$\mathrm{Al}, \mathrm{Cr}, \mathrm{Fe}, \mathrm{Li}, \mathrm{Mg}$, and $\mathrm{Mn}$ have extremes and outliers in the fine mode indicating their anthropogenic origin in these cases (Fig. 2). In addition, the coarse fractions
Fig. 1 Time series of PM for all size-segregated fractions

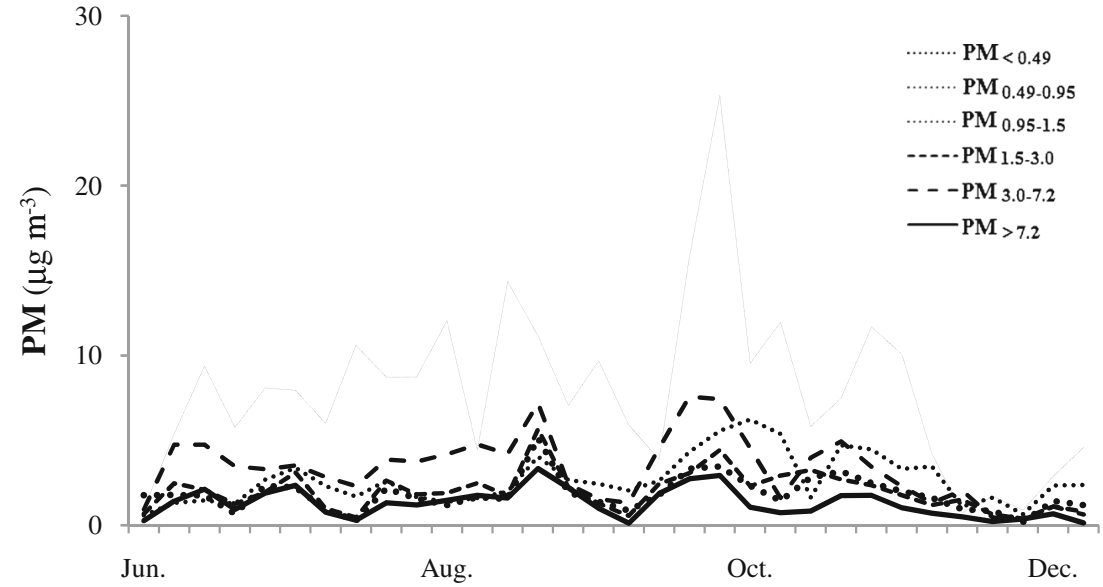


$\left(\mathrm{PM}_{1.5-3.0}, \mathrm{PM}_{3.0-7.2}\right.$, and $\left.\mathrm{PM}_{>7.2}\right)$ contain $\mathrm{K}$ and $\mathrm{PM}_{3.0-}$ 7.2 and $\mathrm{PM}_{>7.2}$ contain Mo. PC2, PC3, PC4, PC5, and PC6 are representing anthropogenic emission sources, combustions, and high temperature processes like metals melting, traffic, industrial heating; fertilizer, oil refinery, and petrochemical plant in nearby industrial city Pančevo located on dominant wind direction (Đorđević et al. 2012) and domestic heating. The second principal component (PC2) with $\sigma^{2} \approx 20 \%$ could be connected with traffic (Table 3).

\section{Cluster analysis}

A cluster analysis (CA) was performed, separately for each $D p$ interval including nuclei mode $\left(\mathrm{PM}_{<0.49}\right)$, accumulation mode $\left(\mathrm{PM}_{0.49-0.95}\right.$ and $\left.\mathrm{PM}_{0.95-1.5}\right)$, and mode of coarse particles $\left(\mathrm{PM}_{1.5-3.0}, \mathrm{PM}_{3.0-7.2}\right.$, and $\left.\mathrm{PM}_{>7.2}\right)$, which points the valuable information of source identification (Đorđević et al. 2004a, b; Contini et al. 2012). The results are reported in Fig. 3. The lower value is on the axis, the more significant are the associations (Facchinelli et al. 2001). The first numbers of stages show the clusters of highest association. The dendrogram of the CA (Fig. 3) on the cumulative data set shows several strong associations, among crustal elements as well as among anthropogenic elements.

In all PM fractions, two main clusters can be notice and could be divided in two groups of elements: (a) originating from resuspension of crustal materials and deposited elements previously emitted from primary sources into the atmosphere and (b) elements of anthropogenic origin from primary emission sources. Resuspension can be linked to $\mathrm{Al}, \mathrm{Ca}, \mathrm{Co}, \mathrm{Cr}, \mathrm{Ga}, \mathrm{Fe}, \mathrm{Mg}$, and $\mathrm{Mn}$ while group of elements of primary anthropogenic origin is $\mathrm{As}, \mathrm{Bi}, \mathrm{Pb}, \mathrm{Sb}, \mathrm{Tl}$, and $\mathrm{Zn}$. Some elements such as $\mathrm{Cd}, \mathrm{Cu}, \mathrm{Li}, \mathrm{Mo}, \mathrm{Na}$, and $\mathrm{U}$ appear in different fractions and seemingly without rules. This could mean that primary sources emit the elements in corresponding fraction or may be due to number of measured values close to the limit of detection such as $\mathrm{Li}, \mathrm{Mo}$, and $\mathrm{U}$ or this analysis may not accurately indicate the origin of $\mathrm{Cu}$ and $\mathrm{Na}$ (Fig. 3). In the fractions of fine mode, $\mathrm{Cd}$ is associated with $\mathrm{Pb}$ indicating common primary source, but it seems that in fractions of the coarse mode, they have separate origin.

The strongest associations were found between $\mathrm{Ni}$ and $\mathrm{V}$ and between $\mathrm{Al}$ and $\mathrm{Mg}$ through all $\mathrm{PM}$ fractions. As presented in CA (Fig. 3), it is evident that the strong association between $\mathrm{Ni}$ and $\mathrm{V}$ exists in all fractions. The $\mathrm{Ni}-\mathrm{V}$ associations in the fine and the accumulation mode and in the fraction $\mathrm{PM}_{1.5-3.0}$ of coarse mode are in the group of elements of primary anthropogenic origin that could be combustion of fossil fuels (Suarez and Ondov
2002; Moffet et al. 2008). Associations of Ni-V presented in fractions of $\mathrm{PM}_{3.0-7.2}$ and $\mathrm{PM}_{>7.2}$ are in the clusters of elements representing the resuspension (Fig. 3). Their strong associations in the fine and the accumulation mode as well as fraction $\mathrm{PM}_{1.5-3.0}$ of coarse mode indicate their common origin from primary anthropogenic emission sources-fossil fuels combustion. The strong $\mathrm{Ni}-\mathrm{V}$ associations in coarse mode is related to resuspended materials previously settled from the atmosphere which were originally emitted from the primary anthropogenic sources. The association $\mathrm{Al}-\mathrm{Mg}$ is strong in all fractions representing the resuspension.

Potassium is associated with anthropogenic elements only in $\mathrm{PM}_{<0.49}$ fraction while in other fractions associated with elements originating from resuspension (Fig. 3). Such distribution of $\mathrm{K}$ indicates the primary emission as combustion process, most probably biomass fuels. The uncertainties in the source apportionment due to impactor losses were already noticed (Contini et al. 2014).

The Spearman coefficients of correlations among variables in all fractions were found for the following pairs: $\mathrm{Al}-\mathrm{Mg}, \mathrm{Fe}-\mathrm{Mn}$, and Ni-V (Table 4). Correlation coefficients of $\mathrm{Al}-\mathrm{Mg}$ association generally are increasing with the increase of the particle size and the highest values are in $\mathrm{PM}_{3.0-7.2}$ and $\mathrm{PM}_{>7.2}$ fractions representing the crustal origin of aluminosilicates. The highest values of correlation coefficients for $\mathrm{Fe}-\mathrm{Mn}$ association were found in $D_{p}$ intervals of coarse particles $\left(\mathrm{PM}_{1.5-3.0}\right.$ and $\mathrm{PM}_{3.0-7.2}$ ) indicating also their origin from crustal substrates. The highest coefficient of correlation of $\mathrm{Ni}-\mathrm{V}$ association is in $\mathrm{PM}_{<0.49}$ fraction and with the increase of the particle size the correlation is decreasing. This indicates the domination of primary emission sources that could be urban traffic in the vicinity of the sampling site. The time series of $\mathrm{Ni}-\mathrm{V}$ couples are shown on Fig. 4. The time series for all fractions are almost identical. This further indicates common emission sources with their simultaneous emissions throughout the whole

Fig. 2 Distribution of elements concentrations with median, interquartile range- $\operatorname{IQR}(Q 1$ as 25 th percentile and $Q 3$ as 75 th percentile), min, max, outliers- $0(>1.5 \mathrm{IQR})$ and extremes - $*(>3 \mathrm{IQR})$ through Dp. Note: (extremes-*: No8: 2 to 4 August 2008; No 14: 7 to 9 September 2008; No 18: 1 to 3 October 2008; No 23: 31 to 2 October/November 2008; No 24: 6 to 8 November 2008; No 31: 18 to 20 December 2008; No 32: 24 to 26 December 2008 (outliers—o: No 2: 27 to 29 June 2008; No 3: 3 to 5 July 2008; No 4: 9 to 11 July 2008; No 6: 21 to 23 July 2008; No 8: 2 to 4 August 2008; No 9: 8 to 10 August 2008; No 11:20 to 22 August 2008; No 12: 26 to 28 August 2008; No 14: 7 to 9 September 2008; No 18: 1 to 3 October 2008; No 19: 7 to 9 October 2008; No 20: 13 to 15 October 2008; No 23: 31 to 2 October/November 2008; No 24: 6 to 8 November 2008 

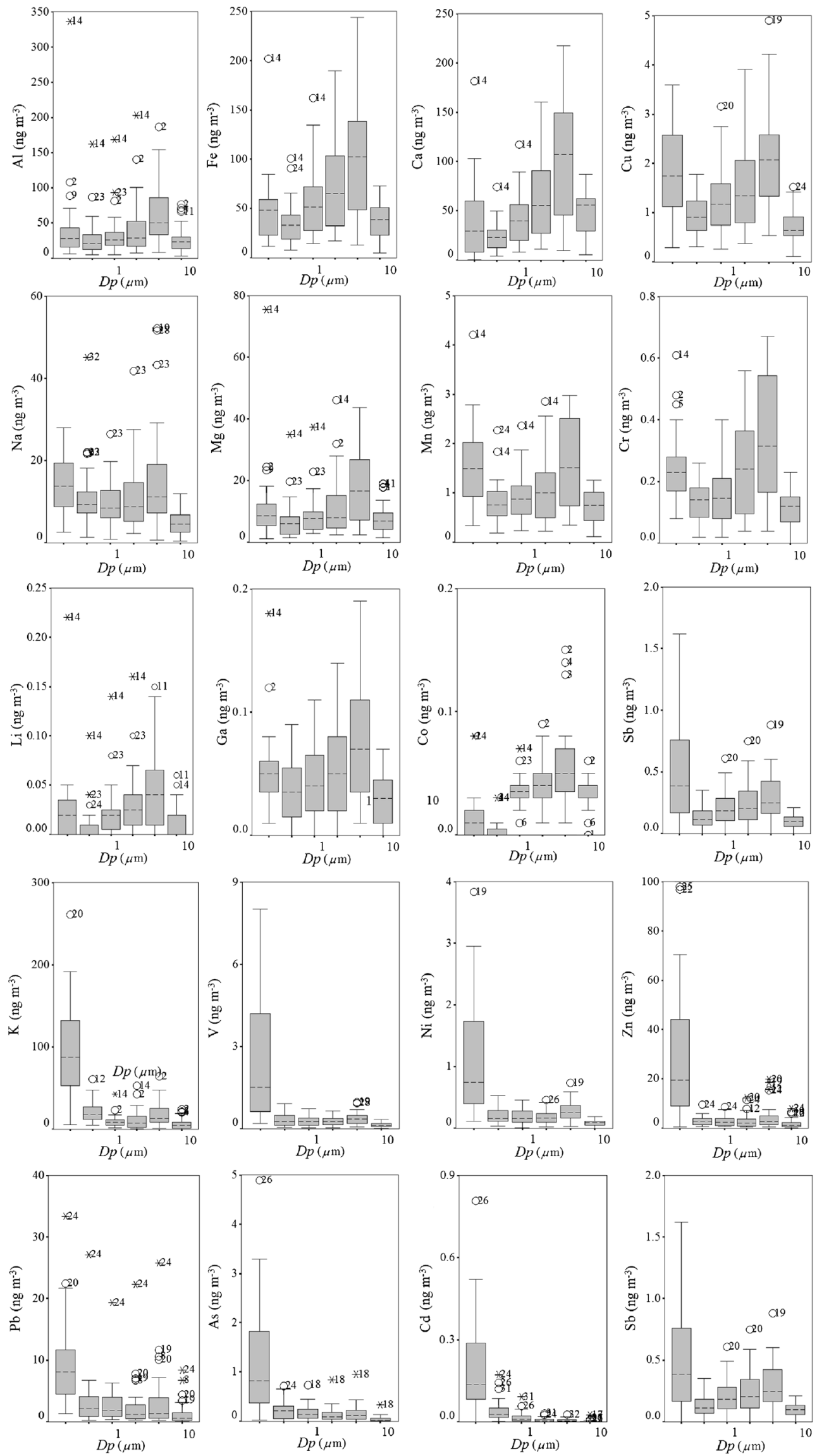
Table 3 Sources identification and contribution by PCA

\begin{tabular}{|c|c|c|c|c|c|c|c|c|c|c|c|c|}
\hline Fraction & $\mathrm{PC} 1$ & $\sigma^{2}(\%)$ & $\mathrm{PC} 2$ & $\sigma^{2}(\%)$ & $\mathrm{PC} 3$ & $\sigma^{2}(\%)$ & $\mathrm{PC} 4$ & $\sigma^{2}(\%)$ & PC5 & $\sigma^{2}(\%)$ & PC6 & $\sigma^{2}(\%)$ \\
\hline $\mathrm{PM}_{<0.49}$ & $\begin{array}{c}\mathrm{Al}, \mathrm{Ca}, \mathrm{Co}, \mathrm{Cr}, \\
\mathrm{Ga}, \mathrm{Fe}, \mathrm{Li} \\
\mathrm{Mg}, \mathrm{Mn}\end{array}$ & 32.57 & $\begin{array}{l}\mathrm{Bi}, \mathrm{Cd}, \mathrm{Pb}, \mathrm{Tl}, \\
\quad \mathrm{Na}\end{array}$ & 16.75 & $\mathrm{Bi}, \mathrm{Cu}, \mathrm{K}, \mathrm{Sb}$ & 14.00 & As, Ni, V & 13.97 & $-\mathrm{Mo}, \mathrm{U}$ & 10.98 & & \\
\hline $\mathrm{PM}_{0.49-0.95}$ & $\begin{array}{c}\mathrm{Al}, \mathrm{Ca}, \mathrm{Co}, \mathrm{Cr}, \\
\mathrm{Ga}, \mathrm{Fe}, \mathrm{Li}, \\
\mathrm{Mg}, \mathrm{Mn}\end{array}$ & 28.22 & $\begin{array}{c}\mathrm{As}, \mathrm{Bi}, \mathrm{Cd}, \mathrm{Cu}, \\
\mathrm{K}, \mathrm{Mn}, \mathrm{Pb} \\
\quad \mathrm{Sb}, \mathrm{Tl}, \mathrm{Zn}\end{array}$ & 25.18 & $-\mathrm{Co},-\mathrm{Mo}, \mathrm{U}$ & 12.59 & $\mathrm{Ni}, \mathrm{V}$ & 10.10 & $\mathrm{Cr}, \mathrm{Cu}, \mathrm{Na}$ & 9.48 & & \\
\hline $\mathrm{PM}_{0.95-1.5}$ & $\begin{array}{l}\mathrm{Al}, \mathrm{Ca}, \mathrm{Co}, \mathrm{Cr}, \\
\mathrm{Ga}, \mathrm{Fe}, \mathrm{K}, \mathrm{Li}, \\
\mathrm{Mg}, \mathrm{Mn}\end{array}$ & 34.14 & $\begin{array}{l}\text { As, } \mathrm{Bi}, \mathrm{Cr}, \mathrm{Cu}, \\
\quad \mathrm{Fe}, \mathrm{Pb}, \mathrm{Sb}, \\
\quad \mathrm{U}, \mathrm{Zn}\end{array}$ & 22.28 & As, Ni, V & 12.31 & $\begin{array}{l}\mathrm{Bi},-\mathrm{Ga}, \\
\quad-\mathrm{Mo}, \mathrm{Tl}\end{array}$ & 10.89 & $-\mathrm{Cd}, \mathrm{Na}$ & 6.27 & & \\
\hline $\mathrm{PM}_{1.5-3.0}$ & $\begin{array}{c}\mathrm{Al}, \mathrm{Ca}, \mathrm{Co}, \mathrm{Cr}, \\
\mathrm{Ga}, \mathrm{Fe}, \mathrm{K}, \mathrm{Li}, \\
\mathrm{Mg}, \mathrm{Mn}, \mathrm{Na}\end{array}$ & 36.31 & $\begin{array}{l}\mathrm{Bi}, \mathrm{Cr}, \mathrm{Cu}, \mathrm{Fe}, \\
\quad \mathrm{Pb}, \mathrm{Sb}, \mathrm{Zn}\end{array}$ & 22.62 & $\mathrm{Ni}, \mathrm{V}$ & 13.10 & $\begin{array}{l}\mathrm{Li},-\mathrm{Mo}, \mathrm{Tl}, \\
\mathrm{U}\end{array}$ & 9.14 & As, Cd & 5.93 & & \\
\hline $\mathrm{PM}_{3.0-7.2}$ & $\begin{array}{c}\mathrm{Al}, \mathrm{Ca}, \mathrm{Co}, \mathrm{Cr}, \\
\mathrm{Ga}, \mathrm{Fe}, \mathrm{K}, \\
\mathrm{Mg}, \mathrm{Mn}, \mathrm{Mo}\end{array}$ & 34.53 & $\begin{array}{l}\mathrm{Bi}, \mathrm{Ca}, \mathrm{Cu}, \mathrm{Fe}, \\
\mathrm{Pb}, \mathrm{Sb}, \mathrm{U}, \\
\mathrm{Zn}\end{array}$ & 22.59 & $\mathrm{Na}, \mathrm{Ni}, \mathrm{V}$ & 11.83 & As, Cd, Tl & 9.31 & $\mathrm{Li}, \mathrm{U}$ & 8.48 & & \\
\hline $\mathrm{PM}_{>7.2}$ & $\begin{array}{l}\mathrm{Al}, \mathrm{Ca}, \mathrm{Co}, \mathrm{Cr}, \\
\mathrm{Ga}, \mathrm{Fe}, \mathrm{K}, \\
\mathrm{Mg}, \mathrm{Mn}, \mathrm{Mo}, \\
\mathrm{Na}\end{array}$ & 34.57 & $\mathrm{Cu}, \mathrm{Pb}, \mathrm{Sb}, \mathrm{Zn}$ & 14.45 & $\begin{array}{l}\text { As, Bi, Co, } \\
\text { Sb, Tl, U }\end{array}$ & 12.17 & $\mathrm{Ni}, \mathrm{V}$ & 10.73 & $\mathrm{Li},-\mathrm{Mo}, \mathrm{U}$ & 8.51 & $\mathrm{Cd}$ & 6.71 \\
\hline
\end{tabular}

The sign "-" in front of the element is indicating negative factor loading $\sigma^{2}$-variance

measurement period. The downward trend in concentrations of $\mathrm{Al}, \mathrm{Mg}, \mathrm{Mn}$, and $\mathrm{Fe}$ from the middle autumn is caused by the emission flux reduction of the resuspension due to wetting of the soil caused by temperature decreasing and increase the relative humidity. For $\mathrm{Ni}$ and $\mathrm{V}$, the evident increase in the concentrations starting from the autumn, especially in nuclei mode, indicates an increase in the number of emission sources from
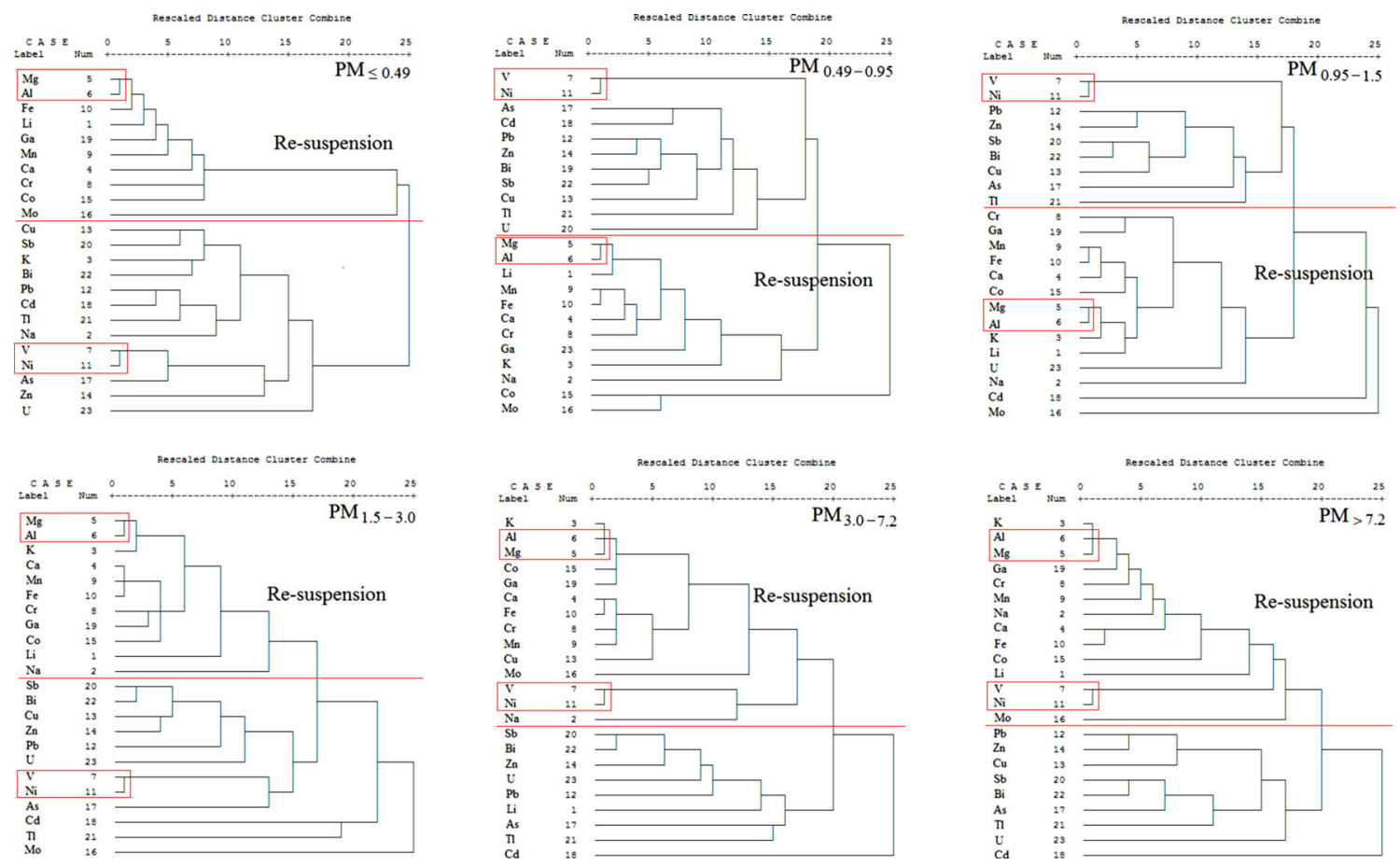

Fig. 3 Cluster analysis of the cumulative data set 
Table 4 The most significant correlations between variables; Spearman's coefficients of correlations $(r)$ on the highest significances levels $(p<0.000)$

\begin{tabular}{lllllll}
\hline Association & $\mathrm{PM}_{<0.49}$ & $\mathrm{PM}_{0.49-0.95}$ & $\mathrm{PM}_{0.95-1.5}$ & $\mathrm{PM}_{1.5-3.0}$ & $\mathrm{PM}_{3.0-7.2}$ & $\mathrm{PM}_{>7.2}$ \\
\hline Al-Mg & 0.848 & 0.772 & 0.824 & 0.894 & 0.966 & 0.955 \\
Fe-Mn & 0.929 & 0.916 & 0.930 & 0.944 & 0.947 & 0.806 \\
Ni-V & 0.978 & 0.969 & 0.973 & 0.955 & 0.941 & 0.908 \\
\hline
\end{tabular}

combustion of fossil fuels with the start of heating season.

\section{Elemental enrichment factors in PM fractions}

In this study, we used enrichment factor (EF) model, which connects elements in the aerosol with their emission sources, to separate the elements of the primary emission sources from those arising from the resuspension (Hlavay et al. 1996). Enrichment factor expressed as $\mathrm{EF}=(X / R)_{\text {aerosol }} /(X / R)_{\text {crust }}$, where $(X / R)_{\text {aerosol }}$ is the concentration ratio of element $X$ to the reference element $R$ in the aerosol, and $(X / R)_{\text {crust }}$ is the concentration ratio of $X$ and $R$ in crust. The values of EF less than 10 indicate the crustal source while elements with higher EFs have a significant anthropogenic source. Aluminum was used as the reference element. Pan et al. (2013) have reported that EF values higher of 100 were significantly higher than historical data recorded in the 1980 s and $1990 \mathrm{~s}$.

Average EF values with appropriate standard deviations for each investigated fraction are presented in Fig. 5. In all fractions $\mathrm{Mg}, \mathrm{Fe}, \mathrm{Ca}$, and $\mathrm{Co}$ are of strictly crustal origin, but in fine mode, small part of Mn has anthropogenic contribution. The majority origin of $\mathrm{Cr}$ is crustal material while small part of anthropogenic origin was noticed in all fractions.

In $\mathrm{PM}_{<0.49}$ fraction, the majority part of $\mathrm{Cd}, \mathrm{K}, \mathrm{V}, \mathrm{Ni}$, $\mathrm{Cu}, \mathrm{Pb}, \mathrm{Zn}$, and $\mathrm{As}$ has the anthropogenic origin; $\mathrm{As}$ and $Z n$ have significantly high EF values-higher than 100. In the next fraction $\left(\mathrm{PM}_{0.49-0.95}\right)$, the majority origin of $\mathrm{K}$, $\mathrm{Ni}$, and $\mathrm{V}$ is crustal, and in $\mathrm{PM}_{0.95-1.5}$ and in coarser fractions, the origin of $\mathrm{K}$ is strictly crustal while in the same fractions main origin of $\mathrm{Ni}$ and $\mathrm{V}$ is crustal also (Fig. 5).

For $\mathrm{As}, \mathrm{Cu}, \mathrm{Pb}$, and $\mathrm{Zn}$ the anthropogenic origin is dominant in all PM fractions except that the larger contribution of anthropogenic sources is in the fine mode (Fig. 5).

The characterization of size-segregated atmospheric aerosols carried out in Budapest, Hungary revealed that most elements in the coarse size fraction had crustal EFs close to one, suggesting soil and road dust dispersal and resuspension as sources. Some elements, i.e., $\mathrm{S}, \mathrm{Cl}, \mathrm{Cu}, \mathrm{Zn}, \mathrm{Ge}, \mathrm{As}, \mathrm{Se}, \mathrm{Br}, \mathrm{Mo}, \mathrm{Ru}, \mathrm{Sb}, \mathrm{I}$, $\mathrm{W}, \mathrm{Au}$, and $\mathrm{Pb}$ were significantly enriched. In the fine size fraction, $\mathrm{S}, \mathrm{Cl}, \mathrm{Cu}, \mathrm{Zn}, \mathrm{Ge}, \mathrm{As}, \mathrm{Se}, \mathrm{Br}, \mathrm{Mo}, \mathrm{Cd}$, $\mathrm{Sb}, \mathrm{I}, \mathrm{W}, \mathrm{Au}, \mathrm{Hg}$, and $\mathrm{Pb}$ had very high EFs, pointing to their anthropogenic origin. $\mathrm{Na}, \mathrm{Mg}, \mathrm{Al}, \mathrm{Si}, \mathrm{P}, \mathrm{Ca}$, $\mathrm{Ti}, \mathrm{Fe}, \mathrm{Ga}, \mathrm{Sr}, \mathrm{Zr}, \mathrm{Mo}$, and $\mathrm{Ba}$ had a unimodal size distribution with most of their mass in the coarse mode
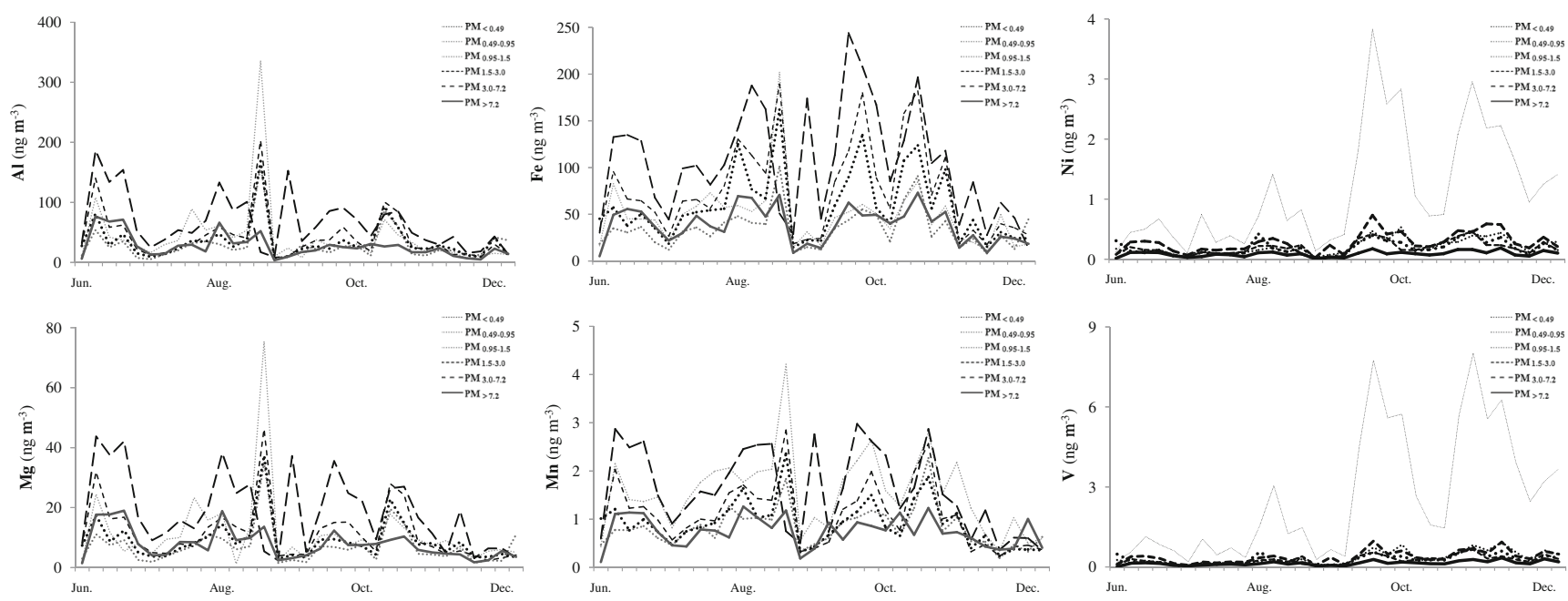

Fig. 4 Time series of $\mathrm{Al}, \mathrm{Mg}, \mathrm{Fe}, \mathrm{Mn}, \mathrm{Ni}$, and $\mathrm{V}$ for all size-segregated fractions 

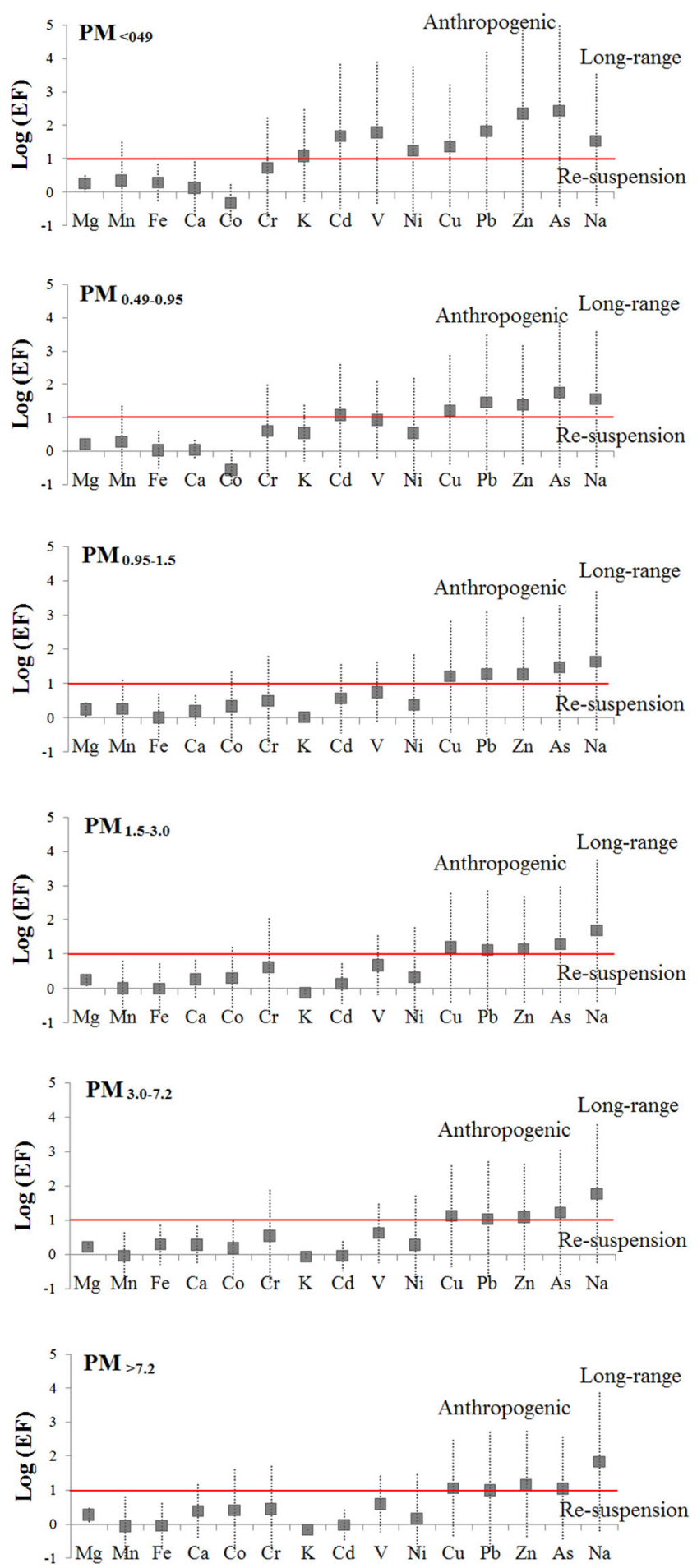

Fig. 5 Enrichment factors in all size-segregated fractions (Al-reference element)

indicating that they were attributable to dispersion, and soil and road dust resuspension processes. On the other hand, S, CI, K, V, Cr, Mn, Ni, Cu, Zn, Ge, As, Se, Br, $\mathrm{Rb}$, and $\mathrm{Pb}$ either had a unimodal size distribution with their mass occurring primarily in the accumulation mode or exhibit clearly a bimodal size distribution at the urban background site. Significant mass in the fine particles pointed to high-temperature sources (Salma et al. 2001).

In all fractions, the average values and standard deviations of $\mathrm{EF}$ for $\mathrm{Na}$ are similar indicating the emission sources that are not of crustal origin. High values of $\mathrm{Na}$ can be attributed to long-range transport. In our previous work (Đorđević et al. 2012), we assumed the impact of marine aerosol on urban aerosol of continental part of Balkan, most probably from the Mediterranean region and from the Atlantic. Zhao et al. (2013) have reported that $\mathrm{Na}$ could have the major marine origin.

\section{Conclusion}

The main difference in mass concentrations of investigated elements in continental urban aerosol was noticed. The maximum contribution is in the $\mathrm{PM}_{1.5-3.0}$ fraction while the smallest contribution is in the $\mathrm{PM}_{0.49}$ fraction. As, $\mathrm{Cd}, \mathrm{K}, \mathrm{Ni}, \mathrm{Pb}$, and $\mathrm{Zn}$ dominate in the fine mode pointing to the combustion process as emission sources while main presence of $\mathrm{Al}, \mathrm{Ca}, \mathrm{Co}, \mathrm{Fe}$, and $\mathrm{Mg}$ in the coarse mode indicates resuspension process. The resuspension and traffic together are contributing with around $50 \%$ of elements in the investigated urban aerosol. The strongest associations were found between $\mathrm{Al}-\mathrm{Mg}, \mathrm{Fe}-$ $\mathrm{Mn}$, and $\mathrm{Ni}-\mathrm{V}$ in all size-segregated fractions. The first two indicating the resuspension while $\mathrm{Ni}-\mathrm{V}$ association indicating the fossil fuels combustion. EF model separated the resuspension from anthropogenic influence in all fractions while long-range transport noticed for Na. The influence of marine aerosol $(\mathrm{Na})$ is the most probably from the Mediterranean region and from the Atlantic.

This approach is useful for assessing the contribution of the local resuspension of crustal elements and elements previously settled from anthropogenic sources on element's contents in the aerosol but also for the evaluation of historical pollution of soil caused by deposition of metals from the atmosphere.

Acknowledgments This work was supported by the INTERREG/ CARDS-PHARE Adriatic New Neighbourhood Programme - Grant No. 06SER02/01/04. The authors are grateful to the Delegation of the European Union to Serbia. The authors were also grateful to the Ministry of education, Science and Technological Development which further supported financially this research within the projects 172001 and 43007. 


\section{References}

Allen AG, Nemitz E, Shi JP, Harrison RM, Greenwood JC (2001) Size distributions of trace metals in atmospheric aerosols in the United Kingdom. Atmos Environ 35:4581-4591

Aničić M, Tasić M, Frontasyeva MV, Tomašević M, Rajšić S, Mijić Z, Popović A (2009) Active moss biomonitoring of trace elements with Sphagnum girgensohnii Moss bags in relation to atmospheric bulk deposition in Belgrade, Serbia. Environ Pollut 157:673-679

Belis CA, Karagulian F, Larsen BR, Hopke PK (2013) Critical review and meta-analysis of ambient particulate matter source apportionment using receptor models in Europe. Atmos Environ 69:94-108

Brüggemann E, Gerwig H, Gnauk T, Müller K, Herrmann H (2009) Influence of seasons, air mass origin and day of the week on sizesegregated chemical composition of aerosol particles at a kerbside. Atmos Environ 43:2456-2463

Buccolieri A, Buccolieri G, Cardellicchio N, Dell'Atti A, Florio ET (2005) Metals content in atmospheric particulate matter collected from an urban area of Abulia (Southern Italy). Ann Chim 95:15-25

Contini D, Belosi F, Gambaro A, Cesari D, Stortini AM, Bove MC (2012) Comparison of PM10 concentrations and metal content in three different sites of the Venice Lagoon: an analysis of possible aerosol sources. J Environ Sci 24:1954-1965

Contini D, Cesari D, Genga A, Siciliano M, Lelpo P, Guascito MR, Conte M (2014) Source apportionment of size-segregated atmospheric particles based on the major water-soluble components in Lecce (Italy). Sci Total Environ 472(2014):248-261

Đorđević D, Vukmirović Z, Tosić I, Unkasević M (2004a) Contribution of dust transport and resuspension to particulate matter levels in the Mediterranean atmosphere. Atmos Environ 38:3637-3645

Đorđević D, Radmanović D, Mihajlidi-Zelić A, Ilić M, Pfendt P, Vukmirović Z, Polić P (2004b) Associations of trace elements in aerosol at the south Adriatic coast. Environ Chem Lett 2:147-150

Đorđević D, Mihajlidi-Zelić A, Relić D, Lj I, Huremović J, Stortini AM, Gambaro A (2012) Size-segregated mass concentration and water soluble inorganic ions in an urban aerosol of the Central Balkans (Belgrade). Atmos Environ 46:309-317

Facchinelli A, Sacchi E, Mallen L (2001) Multivariate statistical and GISbased approach to identify heavy metal sources in soils. Environ Pollut 114:313-324

Handler M, Puls C, Zbiral J, Marr I, Puxbaum H, Limbeck A (2008) Size composition of particulate emission from motor vehicles in the Kaisermühlen-Tunnel, Vienna. Atmos Environ 42:2173-2186

Hlavay J, Polyák K, Bódog I, Molnár Á, Mészáros E (1996) Distribution of trace elements in filter-collected aerosol samples. Fresenius J Anal Chem 354:227-232

Koulouri E, Saarikoski S, Theodosi C, Markaki Z, Gerasopoulos E, Kouvarakis G, Mäkelä T, Hillamo R, Mihalopoulus N (2008) Chemical composition and sources of fine and coarse aerosol particles in the Eastern Mediterranean. Atmos Environ 42:6542-6550

Lawrence S, Sokhi R, Ravindra K, Mao H, Prain HD, Bull ID (2013) Source apportionment of traffic emissions of particulate matter using tunnel measurements. Atmos Environ 77:548-557

Ning Z, Polidori A, Schauer JJ, Sioutas C (2008) Emission factors of PM species based on freeway measurements and comparison with tunnel and dynamometer studies. Atmos Environ 42:3099-3114

Ntziachristos L, Ning Z, Geller MD, Sheesley RJ, Schauer JJ, Sioutas C (2007) Fine, ultrafine and nanoparticle trace element compositions near a major freeway with a high heavy-duty diesel fraction. Atmos Environ 41:5684-5696

Moffet RC, Desyaterik Y, Hopkins RJ, Tivanski AV, Gilles MK, Wang Y, Shutthanandan V, Molina LT, Abraham RG, Johnson KS, Mugica V, Molina MJ, Laskin A, Prather KA (2008) Characterization of Aerosols
Containing $\mathrm{Zn}, \mathrm{Pb}$ and $\mathrm{Cl}$ from an Industrial Region of Mexico City. Environ Sci Technol 42:7091-7097

Murphy DM, Hudson PK, Cziczo DJ, Gallavardin S, Froyd KD, Johnston MV, Middlebrook AM, Reinard MS, Thomson DS, Thornberry T, Wexler AS (2007) Distribution of lead in single atmospheric particles. Atmos Chem Phys 7:3195-3210

Ondov JM, Wexler AS (1998) Where do particulate toxins reside? An improved paradigm for the structure and dynamics of the urban midAtlantic aerosol. Environ Sci Technol 32:2547-2555

Ondráček J, Schwarz J, Ždímal V, Andělová L, Vodička P, Bízek V, Tsai C-J, Chen S-C, Smolík J (2011) Contribution of the road traffic to air pollution in the Prague city (busy speedway and suburban crossroads). Atmos Environ 45:5090-5100

Pacyna JM (1998) Source inventories for atmospheric trace metals. In: Harrison RM, van Grieken RE (eds) Atmospheric particles, IUPAC series on analytical and physical chemistry of environmental systems, vol 5. Wiley, Chichester, pp 385-423

Pan Y, Wang Y, Sun Y, Tian S, Cheng M (2013) Size-resolved aerosol trace elements at a rural mountainous site in Northern China: importance of regional transport. Sci Total Environ 461-462:761-771

Pietrodangelo A, Salzano R, Rantica E, Perrino C (2013) Characterisation of the local topsoil contribution to airborne particulate matter in the area of Rome (Italy). Atmos Environ 69:1-14

Pikridas M, Tasoglou A, Florou K, Pandis SN (2013) Characterization of the origin of fine particulate matter in a medium size urban area in the Mediterranean. Atmos Environ 80:264-274

Pio C, Mirante F, Oliveira C, Matos M, Caseiro A, Oliveira C, Querol X, Alves C, Martins N, Cerqueira M, Camões F, Silva H, Plana F (2013) Size segregated chemical composition of aerosol emissions in an urban road tunnel in Portugal. Atmos Environ 71:15-25

Public Utility Company Beogradske elektrane, www.beoelektrane.rs

Reponen T, Grinshpun SA, Trakumas S, Martuzevicius D, Wang ZM, LeMasters G, Lockey JE, Biswas P (2003) Concentration gradient patterns of aerosol particles near interstate highways in the Greater Cincinnati airshed. J Environ Monit 5:557-562

Salma I, Maenhaut W, Zemplén-Papp É, Záray G (2001) Comprehensive characterisation of atmospheric aerosols in Budapest, Hungary: physicochemical properties of inorganic species. Atmos Environ 35:4367-4378

Seinfeld JH, Pandis SN (1998) Atmospheric chemistry and physics: from air pollution to climate change. Wiley, New York

Song F, Gao Y (2011) Size distributions of trace elements associated with ambient particular matter in the affinity of a major highway in the New Jersey-New York metropolitan area. Atmos Environ 45: 6714-6723

Stortini AM, Freda A, Cesari D, Cairns WRL, Contini D, Barbante C, Prodi F, Cescon P, Gambaro A (2009) An evaluation of the PM2.5 trace elemental composition in the Venice lagoon area and an analysis of the possible sources. Atmos Environ 43:6296-6304

Suarez AE, Ondov JM (2002) Ambient aerosol concentrations of elements resolved by size and by source: contributions of some cytokine-active metals from coal- and oil-fired power plants. Energy Fuel 16:562-568

Tsitouridou R, Papazova P, Simeonova P, Simeonov V (2013) Chemical and statistical interpretation of sized aerosol particles collected at an urban site in Thessaloniki, Greece. J Environ Sci Health A Toxic/ Hazard Subst Environ Eng 48(14):1815-1828

Witt MLI, Meheran N, Mather TA, de Hoog JCM, Pyle DM (2010) Aerosols trace metals, particle morphology and total gaseous mercury in the atmosphere of Oxford, UK. Atmos Environ 44:1524 1538

Zhao M, Zhang Y, Ma W, Fu W, Yang X, Li C, Zhou B, Yu Q, Chen L (2013) Characteristics and ship traffic source identification of air pollutants in China-s largest port. Atmos Environ 64:277-286 